\title{
Learning from Demonstration? Developing Construction for Sustainability
}

\author{
Christian Koch $^{1, *}$ and Niels Haldor Bertelsen ${ }^{2}$ \\ ${ }^{I}$ Chalmers University of Technology, Sven Hultinsgata 8, SE-41296 Gothenburg, Sweden; ${ }^{2}$ Danish Building Research \\ Institute, Aalborg University, A. C. Meyers Vaenge 15, 2450 København, Denmark
}

\begin{abstract}
Demonstration projects are often used in the building sector to provide a basis for using new processes and/or products. The climate change agenda implies that construction is not only required to deliver value for the customer, cost reductions and efficiency but also sustainable buildings. This paper reports on an early demonstration project, the building of a passive house dormitory in the Central Region of Denmark in 2006-2009. The project was supposed to deliver value, lean design, prefabrication, quality in sustainability, certification according to German standards for passive houses, and micro combined heat and power using hydrogen. Using sociological and business economic theories of innovation, the paper discusses how early movers of innovation tend to obtain only partial success when demonstrating their products and often feel obstructed by minor details. The empirical work encompasses both an evaluation of the design and construction process as well as a post-occupancy evaluation. Process experiences include the use of a multidisciplinary competence group and performance measurement. The commencement of the project was enthusiastic, but it was forced into more traditional forms of control, driven by such challenges as complying with cost goals, the need to choose a German prefab supplier, and local contractors. Energy calculations, indoor climate, issues related to square meter requirements, and the hydrogen element became problematic. The aim to obtain passive house certification prevailed over realizing a good indoor climate, which included sufficient heating. Project management must be able to handle quantitative complexity where simple issues add up to major challenges.
\end{abstract}

Keywords: Demonstration projects, innovation, learning, prefabrication, passive houses, Denmark.

\section{INTRODUCTION}

Demonstration projects are a tool often used to achieve innovation in construction $[1,2]$. Zero-carbon housing is gradually being realized as ideas take form that move into constructed products from vision toward articulated and regulated public goals and increasing the challenges of commercialization, following a well-known trajectory of innovation. This development has also involved numerous demonstration projects. The pressure for commercialization involves improving the balance between price and value as well as the performance of sustainable housing in assuring product and process development in response to climate change. In a Danish context, some sustainable housing types have received the reputation of being too expensive and not living up to clients expectations in terms of building performance, understood for example as indoor climate and the daily living function of the house [3, 4]. Isover (2010) [3] thus finds that in a clustered demonstration project realized in Denmark, passive houses are 6-12\% more expensive than comparable traditional housing; and Larsen \& Brunsgaard (2010) [5] and Larsen et al. (2012) [4] find that some heating and cooling issues were experienced by occupants of the passive houses in the same demonstration project.

This article therefore aims to analyze a demonstration project as part of the commercialization of design and the innovation process - including a set of product and process

*Address correspondence to this author at the Chalmers University of Technology, Sven Hultinsgata 8, SE-41296 Gothenburg, Sweden;

Tel: +46 31772 1959; Mobile: +46 76634 5122;

E-mail: christian.koch@chalmers.se concepts. The specific demonstration project realized new student accommodations built from 2006 to 2009. It encompassed four sustainable buildings with a total of 66 rooms each designed according to German norms for passive houses and at a reasonable cost. The demonstration project also included testing of a new combined micro heat and power (mCHP) unit using hydrogen, a unit for electrolysis, and an installation for storage of hydrogen. When initiated, it was an early passive house project and the first building of more than single houses in Denmark. As such, it was a stand-alone demonstration project for passive housing [6]. In relation to process innovation in social housing in Denmark, however, it was one in a series of demonstration projects [7]. Although during the period 2006-2010, sustainable bungalows and houses were gradually moving closer to the commercial market [8], other types of sustainable buildings such as apartment buildings, dormitories, office and institutional buildings were less common $[8,9]$. A number of dynamics led, therefore, to demonstration projects and other attempts to market and brand sustainable buildings and their efficiency, and paved the way toward more such buildings. The $\mathrm{mCHP} /$ hydrogen element with its storage unit was also a really unique technical element.

The main theoretical approach used in this analysis to conceptualize the role of demonstration projects and field trials is innovation theory $[6,10]$. This approach is combined with science, technology and society elements [11] and more experientially based evaluations of demonstration projects $[1,2]$. These combined perspectives on demonstration projects contribute to seeing commercialization as a particularly important phase in carrying out innovation in construction. 
Demonstration projects are often assumed to be of technical or product trial type and the commercialization of design and production processes is overlooked. Moreover, in a construction context, process trials and improvements are equally as important as product trials.

The article has the following structure: Method, theoretical framework, case description, results and discussion, and conclusion.

\section{METHOD}

The paper adopts an interpretive innovation sociological perspective as main orientation, combining innovation theory, STS (Science, Technology and Society), engineering and sociology. In an interpretive sociology perspective focus is on how the innovation is interpreted by actors/stakeholders involved with it $[12,13]$. Demonstration projects are an under-conceptualized research object, even though it is a frequently used mechanism in government-funded development efforts. The innovation theory oriented conceptualization of Brown \& Hendry, (2009) [10] and Hendry et al., (2010) [6] is used here, with modifications that address construction sector characteristics $[1,2]$.

The process of the demonstration project was followed as it emerged from 2006 to 2010. One author followed the process as an evaluator, from the planning of the evaluation in January 2007 to the publication of the evaluation report in October 2010 [14]. The evaluation of the demonstration project was divided into three steps.

First step was implemented parallel to the design and planning process and was a self-evaluation of the cooperation in the competence group from November 2006 to February 2008. Fourteen of the competence meetings minutes, including a common planning meeting and a midway evaluation meeting, comprised the main source for the first part of the evaluation. The competence group consisted of the main actors in the project, and they were responsible for the innovation and exchange of experiences in the demonstration project. In five of the meetings - meetings $6,7,8,9$ and $11-$ the participants answered the same questionnaire with 15 different statements regarding hard and soft competences to be rated using a 10-step scale according to the degree to which they agree with each statement.

Second step was a third-party evaluation of the activities in the design and planning process from November 2006 to August 2008. The evaluation was based on process mappings from records of 31 different meetings, including the competence group meetings. The demonstration project was evaluated according to 25 different topics: seven on innovation, nine on the process, and nine on products and properties. The innovative topics were e.g. passive housing, partnering, hydrogen technology and innovation in the competence group. The process topics were e.g. cooperation, process planning, on-site production, prefabrication, and communication with the occupants. The product topics were e.g. apartments, installations, economy, energy consumption, and indoor climate. The 25 individual topics were selected from the objectives of the demonstration project, and the actual topics were discussed at the meetings [14].
Each of the 25 topics was evaluated by one of the authors in a five-step scale, according to the degree to which the activity was finalized in relation to the time schedule. The interim results were presented and discussed at a common evaluation meeting for all partners in the project in Marts 2010 , one year after delivering the project [14]. At this meeting, the participants reflected on the results and gave their specific comments, explanations of causes, and proposals for future improvements. This reflection meeting and the related analyses were the third step in the evaluation.

In the fourth step of the evaluation, the occupants were asked about their evaluation through circulation of a short questionnaire with 16 questions using the five-step scale. The questionnaire was sent out in March 2010 after one year of occupation, and 18 occupants responded out of about 66 possible. The questionnaire was first introduced late in the process as a result of the reflection meeting in March 2010. It was here stated that the focus of the demonstration project had mainly been on the difficult technical topics such as cost reduction, prefabrication and implementing the $\mathrm{mCHP} /$ hydrogen units, and that the project partners had lost focus on fulfilling the occupants' main expectations. Using occupant questionnaires also involves opening up for communication between tenants and the administrator on minor issues for improvement. Some respondents seem to have used the open commentary field of the questionnaire for such communication.

The limitation of the evaluation project that acts as main basis for this article, is that some parts of the process was less covered than others, both during design and production. The forms used for self-evaluation and for the survey were meant to give indicative results. Also the broader effects of the demonstration project were arrived at by clustering the different innovation effects leading to company and sector learning. The clustering could be with other contemporary and subsequent passive house projects, with competence development initiatives, with the building of organisations and associations facilitating knowledge exchange and dissemination, and also with public regulation (see for example [15]). It is very resource demanding to evaluate all these effects, and we only provide indications of these broader aspects. Another limitation is that the building site and design experiences are only treated marginally. Finally, the paper refrains from dealing with the issue of the design of possible public incentives to improve commercialization.

The paper builds on previous works by the authors [14, 16]. Some references that are only available in Danish are not referenced here, but they are part of the background material.

\section{THEORETICAL FRAMEWORK}

According to Hendry et al. (2010) [6], Brown \& Hendry (2009) [10], demonstration projects are still poorly conceptualized theoretically. They can be understood as "important attempts to shorten the time within which a specific technology makes its way from development and prototype to widespread availability and adoption by industrial and commercial users" [17]. Or they can be understood as in Brown \& Hendry (2009: 2560) [10], who define demonstration projects as "all those activities that expose the technology to 
realistic user environments and are partially funded by the government with the intention of testing its suitability for more extensive diffusion". Commercialization of a product involves some kind of interaction with future users and end customers. Business economists have long observed that commercialization of a product involves a learning curve in which producers, suppliers, and customers gradually modify the product and its related processes [10]. On this background, Brown \& Hendry [10] claim that there is a demonstrated relationship between growth in installations of a new product and reduction in costs resulting from gradually obtained economies of scale [18]; however, the relationship between development in installations and reduction of costs also varies. Nevertheless, the mechanism is often referred to when establishing demonstration projects, viewing them as the final stage before scaling up and underlining the element of possible future repetition and more customers involved, or to be involved. In a construction context, this option of 'scaling up' would be related to industrialization strategies, as in our case analysis below. On the other hand, building projects are often used as vehicles for implementing new elements, field trials and demonstrations, with only a loosely imagined possibility of repetition [1].

Brown \& Hendry (2009) [10] discuss the learning effects related to demonstration projects in terms of three aspects (Brown \& Hendry 2009: 2561) [10]:

1. Reducing uncertainty through new information

2. Progressing towards a dominant design

\section{Developing the socio-technical system}

These three elements are here supplemented with special features related to construction demonstration projects:

First, demonstration projects are supposed to reduce uncertainty by increasing information on the feasibility of the product, economically and technically [6]. Brown \& Hendry (2009) [10] and Geels \& Schott (2008) [11] describe how product development and introduction of innovative elements involves uncertainty and risk. Early design is less proven and, experimentation and further learning are needed in relation to the robustness of the design. Schott \& Geels (2008) [11] outline a set of areas where learning is needed. More specifically, Brown \& Hendry (2009: 2561) [10] note that "[a] particularly critical issue is how the end customer might use the product". The demonstration project, argue Brown \& Hendry, would make the product available to operators and users under controlled and therefore less risky conditions. And the demonstration project would thus provide new information on technological, economic and commercial aspects [10]. It is often noted that demonstration projects tend to be overly focused on showing that the technological aspect 'works', whereas customer needs tend to be abbreviated $[6,10]$.

Second, demonstration projects are stepping-stones in the progress towards a dominant design [10] and a compatible production process. Brown \& Hendry [10] argue that the dominant design is a prerequisite for creating a market for standard products. Importantly, they understand a dominant design as encompassing a particular synthesis of technical aspects with costs and market potential. The establishment of a new dominant design would often occur in a niche environment [11], 'protecting' the new design from competition from other products established by incumbent actors. Often, 'new' products would interact and have interface with other well-known and used technologies and systems, and the present industrialized sustainable building is not an exception. A demonstration can focus on a few core elements, whereas many other elements might be considered more of a known type [10].

Dominant design in construction is not only product design, but also involves design of processes. In construction, it is a condition of the possibility for a demonstration project that it usually involves a dominant process of designing and erecting a building with many recurrent elements in combination with the innovative not-normal processes [1]. Clausen (2002) [1] thus notes that experiences from Danish demonstration projects show that the innovative element has to compete for resources, and that it often loses terrain as the 'routine' core elements of the building attract attention. Project management models and incorporation of innovative elements are needed in demonstration projects to enable establishment of standards for incorporating, for example, energy producing technologies in housing technologies.

Third, the demonstration project is supposed to contribute to developing the socio-technical system. The demonstration does not occur in a vacuum; on the contrary, it also represents the aspiration of being able to initiate broader support for institutional change. A new product and design could be accompanied by dissemination of design knowledge, regulatory change regarding the establishment of new enterprises etc. [19], a process that could also be understood in political terms as developing an advocacy coalition [19]. Schot \& Geels (2008) [11] conceptualize demonstration projects as part of a niche development. They underline the importance of more players and projects that interact and start changing the institutional framework, apart from technical, economic, commercial and social aspects. Brown \& Hendry (2009) [10] underline that the process towards commercialization of projects is not linear. They see a more feasible understanding to involve $\mathrm{R} \& \mathrm{D}$ experimentation along with demonstration projects. These two learning processes - learning-bysearching (R\&D) and learning-by-doing (including demonstrations) - need to be interlinked in the process towards commercialization. In a construction context, however, the $\mathrm{R} \& \mathrm{D}$ element is usually only interwoven directly with the design processes, if present at all. Learning-by-doing dominates, and R\&D is viewed as being close enough to any production-oriented project [1].

To summarize, demonstration projects serve at least three purposes:

- They reduce uncertainty and risk through new information, learning, training and improving competence.

- They advance design and construction methods in both process and product, creating a progression towards a dominant design and compatible production process.

- They achieve broader embedding of the new product and new processes, commencing in a socio-technical context and developing into a socio-technical system. 


\section{A DORMITORY WITH NEW ENERGY SOLUTIONS}

The demonstration project studied was initiated in 2006 with the aim of building dormitories for students at Aarhus University in Herning, Denmark. The innovativeness of the project should be seen in relation to the societal and global context of 2006. The Danish economy and the building sector were booming, based on traditional economy where climate change mitigation played a relatively peripheral role. It was a phenomenon which even to a certain extent was dismissed. Moreover, price development constrained social housing. Only a small handful of players would promote sustainable building or even passive houses.

One of the early movers, or trail blazers, was the nonprofit housing association Fruehøjgaard. The Danish nonprofit social housing sector comprises 540,000 dwellings or nearly $21 \%$ of the total housing stock, and a little less than one million, out of Denmark's population of 5.5 million, live in non-profit housing. This association had participated in innovative projects numerous times over the years, and it wanted to contribute in 2006 to the development of sustainable building in general, and passive houses and hydrogen technology in particular, still maintaining cost efficiency.

The housing association had in the beginning a number of ideas and wishes for the project, aiming to support the vision of the association [14]:

1. Very low energy consumption following a passive house standard

2. Value-based and lean design and planning in partnering

3. Prefabrication of the body of the building with a high energy standard

4. Costs below the maximum amount given with high value

5. Application of the newest hydrogen technology for heating and electricity supply

6. Buildings with focus on architecture fitting to the local environment

7. Buildings with a 'good' indoor climate that the tenants can feel and sense

8. Lean construction, including learning, efficiency and material control on site

These themes and visions communicated both innovative process and product elements - process elements such as value-based lean design and construction; and product elements such as low-cost passive house standard, hydrogen technology, prefabrication, good indoor climate. Aim four refers to the framing and financing system of the social housing sector, which aims to keep costs below the maximum given by the governing ministry. Dwellings are subsidized through tax exemption and financial acquisition combining state subsidized loans (84\%), interest free loans from local governments $(14 \%)$ and tenant contributions $(2 \%)$. The rent is fixed according to costs. This means that the rent is kept affordable by balancing it with the cost of the housing estates' ordinary activities.

The high-energy standard aimed at was made explicit by using the Darmstadt passive house criteria. The four more important criteria are: specific space heating demand should be lower or equal to $15 \mathrm{kWh}$ per $\mathrm{m}^{2}$ per year; the heating load $\leq 10 \mathrm{~W} / \mathrm{m}$; the building envelope should be tight, tested with pressure test and showing air changes $\leq 0.6 / \mathrm{h}$. The specific cooling demand should be $\leq 15 \mathrm{kWh}$ per $\mathrm{m}^{2}$ per year; and the total specific primary energy demand $\leq 120 \mathrm{kWh}$ per $\mathrm{m}^{2}$ per year [20].

The main players were the client, architect, consulting engineer, manufacturer/supplier of prefab elements, the contractors and three suppliers of the Micro Combined Heat and Power (mCHP) unit, the unit for electrolysis, and the hydrogen installation. From 2006, a contractor participated in a collaboration constellation with consultants, but withdrew; and one potential supplier of prefab elements participated until October 2008 but was then substituted with another due to cost concerns.

\section{THE PROCESS OF REALIZING THE DEMONSTRA- TION}

The main phases of the project are shown in Table 1. The building association wished to choose the architect through a competition. This was carried out in September 2006 and led to the selection of an architect and consulting engineer. Subsequently, a search was initiated for ideas and solutions within a passive house concept.

The conceptual design commenced in 2006. In the following, the focus is on three innovative elements: the passive house design, the prefabrication, and the hydrogen technology.

Table 1. Plan as of Early 2007, and Realized Phases of the Building

\begin{tabular}{|c|c|c|}
\hline Main Phases & Plan (2007) & Realized \\
\hline \hline Choice of consultants & 2006, September & 2006, September \\
\hline Conceptual phase & 2006, November-2007, April February \\
\hline Development phase & Not planned & 2007, March-November \\
\hline Design phase & 2007, May-September & 2007, May-2008, May \\
\hline Erection phase & 2007, September-2008, June & 2009, January \\
\hline Occupancy & 2008, July & 2009, July \\
\hline Outdoor areas finished & Not planned as separate & \\
\hline
\end{tabular}


Designing a passive house involves carrying out substantive energy calculations. The early process of meeting the Darmstadt standard and the high energy standard in the Danish Building Regulation (fulfilling the EU directive) involved calculations by the engineering consultant using the Be06 software. Be06 is a Danish calculation program required by the Danish Building Regulation. In the spring of 2007 , issues still remained with regard to meeting the first demand of specific space heating lower or equal to $15 \mathrm{kWh}$ per $\mathrm{m}^{2}$ per year. The calculations showed a net heating demand of $21 \mathrm{kWh}$. By July 2007, the design work was able to meet the certification demands. A lack of clarity prevailed throughout the autumn and early winter, however, and in February 2008, it was decided to ask for consultancy from the Darmstadt experts. This third round of major calculations showed that the third demand of total specific primary energy $\leq 120 \mathrm{kWh}$ per $\mathrm{m}^{2}$ per year could not be met, primarily due to differences in definitions and in relation to the use of hydrogen. Certification was obtained in late 2009, a year after occupation.

The project aimed at obtaining a cost/value relation that was attractive to social housing, and using prefabricated elements was seen as part of this aim. A Danish manufacturer of prefabricated modular building envelope elements participated in the early phase, from January to October 2007. The manufacturer developed a prototype of a room module, but the calculated cost was too high and the manufacturer was dismissed. A shift was made to using facade elements for a passive house building envelope, using a German prefab manufacturer, a collaboration that commenced in November 2007. This can also be seen against the background of the contemporary status of the Danish market for building components. In 2007-2008, the consultant said that no Danish component manufacturer could live up to the project requirements, i.e. the passive house standard.

The aim of using hydrogen technology to transform surplus electricity led to involvement of three supplier specialists. They supplied a mCHP unit, a unit for electrolysis, and a hydrogen installation for storage of hydrogen. Although these parts were ordered early, they were delayed, so the design process began in March and April 2007. A search for supplementary financing was initiated. By August 2007, the hydrogen element was taken out of the project due to lack of funding and technical problems. In November 2007, however, the hydrogen element was back in the project again. The installation became ready immediately before and parallel with the first occupancy in late 2008 and January 2009. The hydrogen element of the design was not independent of the rest of the design, and it led to extra man hours to carry out redesign. In each block of the dormitory four units of the hydrogen system and other heating and ventilation systems for 16 apartments had to be installed in one narrow technical room where the building's full width and height of two floors was used to make way to the entirety of the technical installations.

\section{RESULTS OF THE PROJECT}

The project met the cost goal as originally stated. In the project's final balance, the total cost of erecting the 66 dormitory rooms and the common facility house was 7.35 million euros (54.8 million DKK), inclusive VAT. As the gross built square meters are 3,300 , the cost per square meter is 2,300 euros, which is $92.4 \%$ of the maximum amount of 2,485 euros $/ \mathrm{m}^{2}$ set by Ministry of Social Affairs for the allowed cost for social housing construction. It should be noted however that this was made possible by a budget reduction exercise carried out in May 2007, and that several of the participating companies saw the project as innovative and were willing to put aside part of their costs in terms of hours spent, as they viewed it as an investment in future knowledge and products.

Prefabrication was another stated goal, and the degree of prefabrication is some $59 \%$ calculated on the basis of the contractor's spending. The prefabricated building envelope's cost was thus $52 \%$ of the total contractor's cost, and the bathrooms were $7 \%$ of the costs. In comparison, foundations and outdoor areas comprise $13 \%$, indoor surfaces and indoor furniture and fittings $16 \%$, and installations $19 \%$ of the contractor costs.

The self-evaluation of competence meetings $6,7,8,9$ and 11 and the answers to the 15 statements were analyzed in two groups - one on soft competences and one on hard competences. The soft competences include 10 statements about openness, respect, listening to others, and team spirit, and the hard competences include five statements about an effective process, goals implemented, the right knowledge and preventing problems. The average results of the answers for the two groups are seen in Fig. (1).

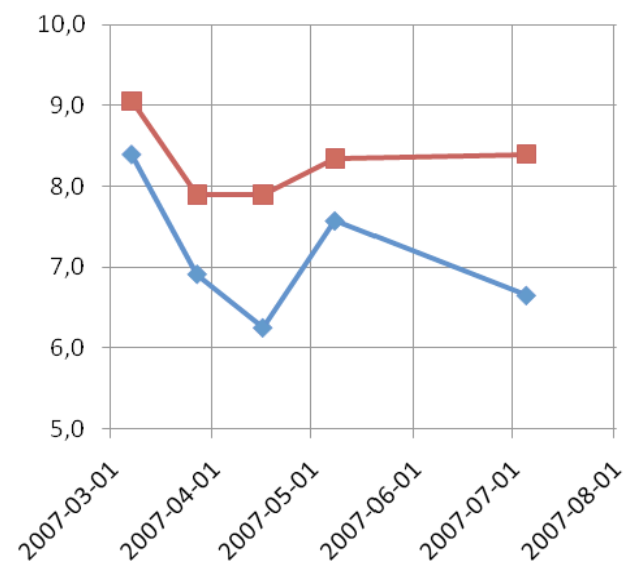

Fig. (1). Average answers in a 10-step scale on competences at five competence meetings. Red is an average of 10 soft competences, whereas blue is an average of five hard competences.

The ratings for all responses in Fig. (1) is high. The figure also shows that the hard competences (in blue) are rated at 8.4 at meeting 6 and that the rating drops to 6.7 at meeting 11 , but with the lowest rating at meeting 8 . The rating on soft competences (in red) is at a higher level compared to the hard competences, and the drop in rating at meeting 8 is not so dramatic. It appears that the group's evaluation of hard competences were better synchronized with the issues arising in the process. In the second step of the evaluation, the third party evaluation of minutes of 31 different meetings throughout a 19-month period was analyzed. For each of the 25 different topics, the degree of finalization of the activity is mapped according to the time schedule. This is illustrated for topic '6 Innovation' in Fig. (2). The activity on innova- 


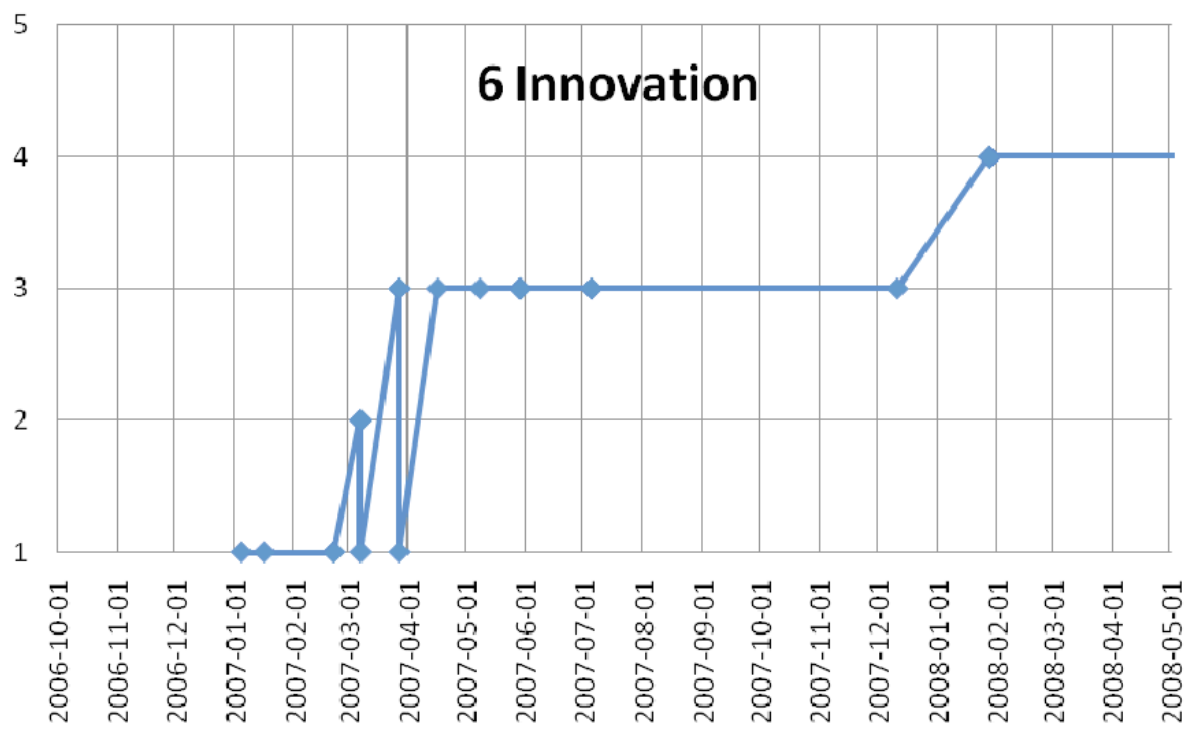

Fig. (2). Progress curve for the topic '6 Innovation', one of 25 topics evaluated. The degree of finalizing the activity is rated in a 5-step scale for each of 31 meetings during a 19-month period.

tion started in January 2007, and three months later, the activity is rated at a 50\% finishing level (rating 3). After nine months, no progress is recorded on the innovation activities, and then one month's activity in January 2008 raises the degree of finalization of the activity to $75 \%$ (rating 4 ). Then, the progress is stopped without finalizing the activity.

If we then analyze the progress curves for all nine process topics and for all nine product topics, we can divide them into three different groups. The first group comprises topics finalized at $25-50 \%$ of finalizing the activity (rating 2-3), the second group comprises topics finalized at $75 \%$ of finalizing the activity (rating 4), and the third and last group comprises topics finalized at $100 \%$ of finalizing the activity (rating 5).

It is seen from the results of the comparison in Table 2 that more process topics are finalized than product topics. The degree of finalizing the activity for the nine product topics centres around $75 \%$ of finalizing the activity.

Table 2. Comparison of Progress Curves for Nine Process and Nine Product Topics

\begin{tabular}{|c|c|c|c|}
\hline & Group of progress curves & $\begin{array}{c}\text { Process } \\
\text { topics }\end{array}$ & $\begin{array}{c}\text { Product } \\
\text { topics }\end{array}$ \\
\hline \hline 1 & Finalizing at $24-50 \%$ (rating 2-3) & 1 & 2 \\
\hline 2 & Finalizing at $75 \%$ (rating 4) & 3 & 6 \\
\hline 3 & Finalizing at $100 \%$ (rating 5) & 5 & 1 \\
\hline
\end{tabular}

The preliminary results of the progress analyses was presented and discussed at a common evaluation meeting one year after delivering the building. Fifteen participants, including the owner, architect, engineers, contractors and process consultant, concluded the following learning from the project:

- Owner: Wants to start better planning, midterm evaluation, clear division of roles, good construction management, embed problem area, and involve residents early.
- Architects: The reason for the good results is team spirit from day one, carried by a visionary owner and the belief: We can - we will - we do it!

- Engineers: Conscious of how and when we enter the process and get the right skills at the right time.

- Contractors: Be better to have an overall picture a little earlier and a clear picture of the final phase, so as to avoid issues that are resolved too late.

- Process consultant: Be aware of when to take the step from development to production and try to avoid clutter in the process.

The occupants have responded positively on a number of aspects of the dormitory in the survey evaluation carried out in 2010, showing that the respondents in the survey value a number of aspects of the rooms and facilities highly. The survey encompassed 17 questions and shows high valuation of the kitchen and bathroom, the floors, the general comfort and daylight. The lowest scores and the most comments, however, concern the response to the question on the heating system and the thermal comfort of the room. The average score on this question is 2.4 on a scale from 1 to 5 . The comments received allude to heating problems in the winter, and the interdependency of the room heating (if one tenant is absent it implies lower heating in another room). There were also cooling problems in the summer. The occupant's evaluation is in contrast to the evaluation of other stakeholders. But it should be noted that indoor climate design played a rather peripheral role in the design process. Documentation for the indoor and energy properties was not provided by the project due to time and resource pressure in the later stage of the project.

\section{DISCUSSION}

The following discussion uses Brown \& Hendry's three dimensions of the aims of demonstration projects, looking also at the project's innovative process and product elements. The three dimensions are learning (reducing uncer- 
tainty through new information), advancing design methods in both process and product (progressing towards a dominant design), and commencing a broader embedding of the new product in its socio-technical context (developing the sociotechnical system).

\section{Reducing Uncertainty Through Learning}

The process experiences of the project are rich, technically, economically and commercially. They encompass the use of a multidisciplinary competence group (value-based design), partnering and performance measurement. After a creative and enthusiastic beginning, however, the process had to be controlled more traditionally, driven by such challenges as those presented by the necessity to choose a German prefab supplier, the local contractors, and the requirements of the economic goals. Energy calculations, indoor climate, and issues regarding the square meter requirements became problematic. The quality goal, formulated as obtaining a passive house certification, was given priority over realizing a good indoor climate, including sufficient heating.

The competency group proved instrumental, especially in the beginning when the project was set up. The subsequent process revealed, however, that a major challenge for the participating players was to tackle three main innovative elements at one time: the prefab building envelope, the passive house design, and the hydrogen electricity conversion and heating system. The learning connected with the product elements was related to low costs, passive house standard, hydrogen technology, prefabrication, and good indoor climate. As noted, costs were maintained within the maximum amount given, which was a major achievement.

The house also achieved the passive house standard from Darmstadt, amongst the first ten in Denmark, as well as the high energy standard in the Danish Building Regulation. The post- occupancy energy consumption has not been measured however. The learning related to obtaining the certification should have provided a competitive platform for the participating companies, at least in the social housing sector at the time.

Brown \& Hendry (2009) [10] underline the important learning that can be gained when involving the end customers. The occupants' evaluation shows a strong general satisfaction with the rooms on a number of dimensions, but experiences with the heating system and temperature adjustment score lowest in the investigation, reflecting yet again that the occupants' behaviour should not be underestimated in relation to climate mitigation buildings (see also [5]).

\section{Advancing and Stabilizing Design Methods}

Several elements of the project contributed to progress towards a dominant and compatible process and product design: the energy calculations, the prefab elements, passive house certification, and process elements mentioned above. The hydrogen technology element belonged however to a much earlier phase of development, and should be viewed more as an early experiment. As subsequent developments in the building and housing sector have emerged, it has become clear that the German passive house certification used is merely one design approach among several on the Danish market for sustainable housing [9]. Several more passive houses emerged from 2006 to 2008 [3, 5]. A competing "active house" concept was launched in 2009, and LEED, BREEAM, cradle-to-cradle etc. also emerged [9]. By 2011, the DGNB (Deutsche Gesellschaft für Nachhaltiges Bauen) certification in 2010-2011 was gaining ground [21], and especially the energy class 1 , which refers to the European Performance of Buildings Directive (EPBD) 2002 [22].

In relation to the application of the German passive house standard in Denmark, it should be noted that the requirements in the Danish Building Regulation could not be complied with by following the German passive house standard alone. Nevertheless, several players have profiled themselves as competent passive house designers and producers, which means still more competition between designs [7]. Similarly, the prefab element of the building envelope complying with passive house standard - this has received relatively little attention, since the producer has only been able to sell his concept in two more cases (see below). Parallel to this, new industrialization efforts are also adopted only reluctantly in Danish construction [23].

\section{Changing and Stabilizing the Socio-Technical System}

The socio-technical systems needed for realizing sustainable prefabricated low-cost buildings encompass a set of players such as architects, engineering consultancies, contractors and clients, in collaboration with educational and research institutions. The hydrogen element is in a sense becoming independent from the rest of the demonstration project and therefore represents the need for an alliance with for example a mCHP unit manufacturer. A stronger grouping of actors could provide and exchange experiences on emerging design and commercialization. Low-cost buildings for social housing and dormitories would constitute a sub-group here.

The project itself involved a study trip to Germany, a website communicating the project's development, and an evaluation meant to stimulate learning. Although in 20062009 several players were advocating passive houses, the advocacy coalition was not strongly established. During this period, two other Danish building projects also in the region of central Denmark (in Lystrup and Ebeltoft) used the same supplier of prefabricated building envelope elements. Here, the supplier collaborated with other players and the project was carried out in parallel. Apart from these two projects, the strategy to use a German prefab player or adopt German building components has had no followers.

From 2009 to 2011, some 2000 guests visited the building, and the project was given two sustainability prizes. In subsequent years, however, building components and housing in Denmark in compliance with German norms have been introduced, which means that the demonstration project concept received competition [3]. Also, the manufacturer/designer of the mCHP unit became interested in another variant of mCHP that uses gas rather than hydrogen; only a few other units, which are not linked with this demonstration, have been installed with hydrogen. Brown \& Hendry (2009) [10] and Hendry et al. (2010) [6] discuss demonstration projects with a large number of installations in- 
volved with a longitudinal perspective. They are able to trace some elements that emerge into a dominant design and even shift in generation of technology.

Our research format leads to a more modest set of conclusions. Although the project has contributed to broader learning in relation to affordable sustainable housing, we cannot claim a change in the socio-technical system in the direction of low-cost prefabricated passive houses. A couple of similar low-cost social housing projects have occurred subsequently. A more general trend towards several types of sustainable low-carbon emission housing is emerging, however, mainly driven by European building directives and regulations $[7,8,16,24]$, where low cost is not necessarily in focus.

A final note: the theory used here for demonstration projects and trials assumes that it possible for the tested product to extend into mass markets in which the present building context would be more of a (customized) design for single or small clusters of customers. Therefore, process testing becomes more important and also constitutes the more difficult part to diffuse.

\section{CONCLUSION}

The demonstration project for sustainable housing studied was supposed to prepare the way for future improved and commercially viable solutions. The project demonstrated that it is possible to build four two-storey buildings with $66 \mathrm{stu}-$ dent apartments according to a passive house standard, while not exceeding the normative costs for social housing. This can be done, however, on the condition that the involved parties in the design and construction process are able to tackle the various aspects of the project and continue using an innovative process.

One such aspect to be tackled was the lack of qualified suppliers of prefabricated building envelope elements, which could fuel the competition to produce energy certified elements of high standard and low price. A second aspect is how quantity and cost are continually controlled, which risks destroying the innovative and learning aspects of a demonstration project. Our recommendation is that the innovation culture of - and between - architects, engineers, constructers and suppliers involved in the individual building projects must be improved with regard to speed and costeffectiveness. This includes the calculation of energy throughout the design process, which must be quicker and adjusted to the needs of the architect and client, and at the same time be related to different standards, e.g. the German passive house standard and the different energy consumption standards in the Danish Regulation and in the European Building Regulation. Demonstration projects are prone to suffer from quantitative complexity, like other building projects, meaning that many details and aspects, which by themselves might appear simple, add up to a complex whole.

The demonstration project occurred during a period when market dynamics drove quick development of competing solutions, meaning that otherwise obvious iterations of design, such as improvement of the indoor climate, was missed and had to be "redone" at other designs. The effects on improved learning in and between innovation and demonstra- tion projects become constrained under such circumstances. Even when they are deemed successful, demonstration project cannot stand alone; they must be followed by other demonstration projects and a systematic dissemination process in the sector.

\section{CONFLICT OF INTEREST}

The author(s) confirm that this article content has no conflicts of interest.

\section{ACKNOWLEDGEMENT}

Declared none.

\section{REFERENCES}

[1] L. Clausen, "Innovationsprocessen i byggeriet - Fra idé til implementering i praksis", Ph.D. Thesis, Technical University of Denmark, Lyngby, 2002 ("The innovation process in Construction from idea to implementation in practice").

[2] H. Smyth, "Construction industry performance improvement programmes: the UK case of demonstration projects in the 'Continuous Improvement' programme", Construction Management and Economics, vol. 28, no. 3, pp. 255-270, 2010.

[3] ISOVER. "Komforthusene - erfaringer, viden og inspiration". Isover Vamdrup, "The comfort houses - experience, knowledge and inspiration" 2010.

[4] T.S. Larsen, R.L. Jensen, and O. Daniels, "The Comfort Houses Measurements and analysis of the indoor environment and energy consumption in 8 passive houses 2008-2011", Aalborg University Aalborg, 2012.

[5] T.S. Larsen, and C. Brunsgaard, "Komforthusene udvikling af passivhuskonceptet $i$ en dansk kontekst", Paper Nordisk Passivhus Conference Ålborg, 2010.

[6] C. Hendry, P. Harborne, and J. Brown, "So what do innovating companies really get from publicly funded demonstration projects and trials? Innovation lessons from solar photovoltaics and wind", Energy Policy, vol. 38, no. 8, pp. 4507-4519, 2010.

[7] H. Davidsen and N. H. Bertelsen (2013). 'Etablering af AlmenNet 2004-09 - Udredning om forløb og resultater af udviklingprogram Fremtidssikring af celdre almene byggebyggelser". Danish Building Research Institute, Aalborg University Copenhagen, Denmark, SBi report 2013:xx (in progress), September 2013. ("Establishment of "AlmenNet 2004-2009" report on process and results of the development program "Future proof" of older social housing")

[8] J. Holm, I. Stauning, and B. Søndergård, "Local climate mitigation and eco-efforts in housing and construction as transition places", Environmental Policy and Governance, vol. 21 no. 1, pp. 183-198, 2011.

[9] M. Buser, and C. Koch, "Multiple institutional dynamics of sustainable housing concepts in Denmark - on the role of passive houses", Sociology Study, vol. 2, no. 10, pp. 725-741, 2012.

[10] J. Brown, and C. Hendry, "Public demonstration projects and field trials: Accelerating commercialisation of sustainable technology in solar photovoltaics", Energy Policy, vol. 37, pp. 2560-2573, 2009.

[11] J. Schot, and F.W. Geels, "Strategic niche management and sustainable innovation journeys: theory, findings, research agenda, and policy", Technology Analysis \& Strategic Management, vol. 20, no. 5, pp. 537-554, 2008.

[12] A. Bryman, and E. Bell, Business Research Methods, Second edition, Oxford University press, Oxford, 2007.

[13] G. Walsham, Interpreting Information Systems in Organizations. Wiley. Chichester. 1993.

[14] N. H. Bertelsen. H2College som præfabrikerede passivhuse - Evaluering af projekteringen af nybygning af 66 kollegieboliger i Herning med fokus på procesoptimering, energi og indeklima. Afprøvning 2010-01, AlmenNet, København, 2010.

[15] E. H. Lauridsen, and J.S. Jensen, "The strictest energy requirements in the world: An analysis of the path dependencies of a selfproclaimed success", Energy Policy, vol. 53, pp. 97-104, 2013. 
[16] N. H. Bertelsen and C. Koch. The Devil in the Detail -The Story of a Sustainable Trail Blazer. In C. Egbu and E.C.W. Lou (Eds) (2011). Proceedings 27th Annual Conference ARCOM conference University of the West of England, Bristol. 2011, pp. 1105- 1114.

[17] S. Lefevre, "Using demonstration projects to advance innovation in energy", Public Administration Review, vol. 44, no. 6, pp. 483-490, 1984.

[18] C-O. Wene, "Experience Curves for Energy Technology Policy". IEA, OECD, Paris, 2000.

[19] T. Foxon, J. Köhler, and C. Oughton, "Innovation in energy systems: Learning from economic, institutional and management approaches". Edward Elgar. London, 2008.

[20] Darmstadt standard, downloaded from http://www.passiv.de/ March 2013

[21] H. Birgisdottir, K. Hansen, K. Haugbølle, P. Hesdorf , I.S. Olsen, and S. Mortensen, "Baredygtigt byggeri-Afprøvning af certifice- ringsordninger til måling af baredygtighed i byggeri", Byggeriets Evalueringscenter. Copenhagen, 2010.

[22] EU, "Directive 2002/91/EC of the European Parliament and of the Council of 16 December 2002 on the Energy Performance of Buildings". Bruxelles: European Commission. (abbreviated EPBD). 2002.

[23] C. Thuesen, and C. Koch, "Mapping Innovation: Facilitating Innovation in the Danish Construction Industry", In: K. Haugbølle, S Gottlieb, K.E. Kähkönen, O. Klakegg, G. Lindahl , and K. Widén, Eds. Proceedings of the 6th Nordic Conference on Construction Economics and Organisation. vol 3. Danish Building Research Institute, Aalborg University, pp. 641- 652, 2011.

[24] R. Marsh, V.G. Larsen, and M. Kragh, "Housing and energy in Denmark: past, present, and future challenges", Building Research \& Information, vol. 38, no. 1, pp. 92-106, 2010.

(C) Koch and Bertelsen; Licensee Bentham Open.

This is an open access article licensed under the terms of the Creative Commons Attribution Non-Commercial License (http://creativecommons.org/licenses/by-nc/3.0/) which permits unrestricted, non-commercial use, distribution and reproduction in any medium, provided the work is properly cited. 